\title{
Texas Excavations at Site 41FB191 (Jester Farm Site \#1) Fort Bend County, Texas
}

Alan J. Wormser

Follow this and additional works at: https://scholarworks.sfasu.edu/ita

Part of the American Material Culture Commons, Archaeological Anthropology Commons, Environmental Studies Commons, Other American Studies Commons, Other Arts and Humanities Commons, Other History of Art, Architecture, and Archaeology Commons, and the United States History Commons

Tell us how this article helped you.

This Article is brought to you for free and open access by the Center for Regional Heritage Research at SFA ScholarWorks. It has been accepted for inclusion in Index of Texas Archaeology: Open Access Gray Literature from the Lone Star State by an authorized editor of SFA ScholarWorks. For more information, please contact cdsscholarworks@sfasu.edu. 


\section{Texas Excavations at Site 41FB191 (Jester Farm Site \#1) Fort Bend County, Texas}

\section{Licensing Statement}

This is a work produced for the Texas Department of Transportation (TxDOT) by the report producer. TxDOT and the report producer jointly own all rights, title, and interest in and to all intellectual property developed under TXDOT's contract with the report producer. The report may be cited and brief passages from this publication may be reproduced without permission provided that credit is given to both TXDOT and the report producer. Permission to reprint an entire chapter, section, figures or tables must be obtained in advance from either the Supervisor of the Archeological Studies Branch, Environmental Affairs Division, Texas Department of Transportation, 125 East 11th Street, Austin, Texas, 78701 or from the report producer 


\title{
TEST EXCAVATIONS \\ AT SITE 41FB191 (JESTER FARM SITE \#1) \\ FORT BEND COUNTY, TEXAS
}

\author{
Alan J. Wyormser
}

Texas

State Department of Highways and Public Transportation Highway Design Division

July 1990 


\section{ABSTRACT}

Site 41FB191 is a camp site dating to the Late Archaic/Early Ceramic time period northwest of Oyster Creek inFort Bend County. The site was found by a member of the State Department of Highways and Public Transportation (SDHPT) cultural resources staff during a routine archaeological survey for the proposed Segment "D" of SH 99 (Grand Parkway). When it was firstlocated, the site had just been plowed and a number of flakes and a biface tip were found on the surface. Based on the amount of surface debris, testing was recommended inorder to determine eligibility for the National Register of Historic Places (NHRP).

The site was tested in early June 1990, when three test units, three Gradall trenches and six shovel tests were excavated. This testing revealed that the site has undergone erosion and deflation through a century of agricultural activity. Animal disturbance was also present in one of the test units. All of the stone tools and most of the other artifacts were found at the surface or within the plow zone and no features were encountered.

As a result of our investigation, it appears that construction of this portion of $\mathrm{SH} 99 \mathrm{will}$ not disturb significant archaeological remains at 41FB191. 
ABSTRACT .................... . . $\mathbf{i} \mathbf{i}$

TABLE OF CONTENTS. . . . . . . . . . . . . . . . . . . i i i i LIST OF FIGURES ...................... . . iv

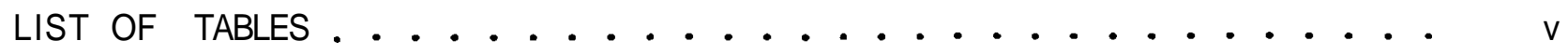

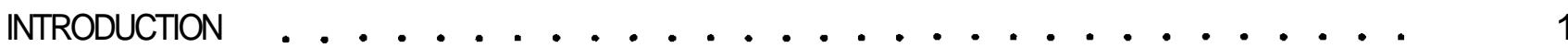

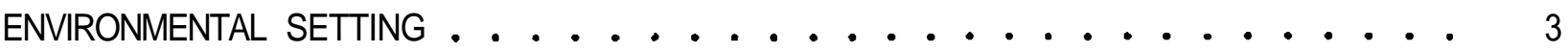

CULTLIRAL SETTING . . . . . . . . . . . . . . . . 4 Previous Archaeological Research ............ 4

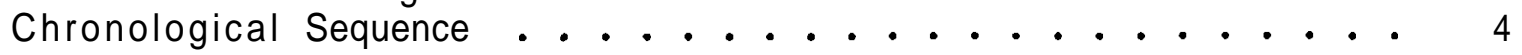

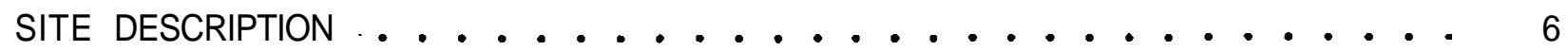

TEST EXCAVATIONS .............................. 7

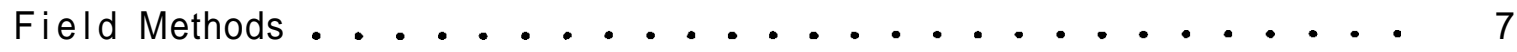

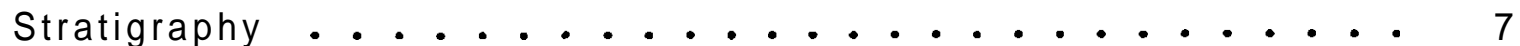

Test Units.................... . . 10

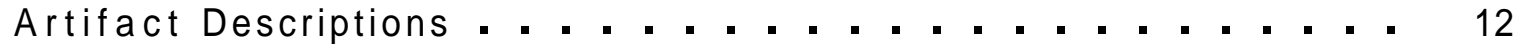

CONCLUSIONS . . . . . . . . . . . . . . . . . . . 17

REFERENCES CITED . . . . . . . . . . . . . 18 


\section{LIST OF FIGURES}

Figure 1. Location of Site 41FB191. ............. 2

Figure 2. Test units. trenches, and shovel tests at 41FB191. . . . . 8

Figure 3. Stratigraphic profiles. Trenches 2 and 3. . . . . . . . 9

Figure 4. Test Unit 3. North wall profile and composite plan view. . . 11

Figure 5. Artifacts from 41FB191. ............. 14 


\section{LIST OF TABLES}

Table 1. Summary of artifacts found at 41FB191. . . . . . . . . . 13 


\section{INTRODUCTION}

Site 41FB191 extends across two terraces on the southeast side of a marshy area at the Jester Prison Farm (Figure 1). The marshy area may represent an ancient channel of Oyster Creek, which today flows about 1 kilometer to the southwest. The site is in a cultivated field which has been repeatedly plowed for decades. At the time of our first visit to the site in November 1989, the field had just been plowed. By the time the site was tested in June, hay had just been harvested. Agricultural fields and pasture surround the field containing 41FB191.

The SDHPT plans to construct Segment "D" of SH 99 (Grand Parkway) and 41FB191 is within the proposed right-of-way for the project. Initial survey of the site indicated that there was a light to moderate scatter of lithic debris on the surface. Based on our observations, testing was suggested in order to determine eligibility for the National Register of Historic Places (NRHP). Testing commenced during the first week of June 1990 with a crew of 4 persons supplied by the State Mental Health-Mental Retardation Set Aside Program. Three 1x1 meter test units were excavated along with six shovel tests and three Gradall trenches. Matrix from the test units was screened through 1/4inch hardware cloth.

Artifact recovery was restricted to the upper $20 \mathrm{~cm}$ of deposit, except in a portion of Test Unit \#3 where there was animal disturbance. In general, cultural debris is on the surface or within the plow zone. No features were found, and it is likely that any features which survived into modern times were shallow and have been obliterated by plowing. The only chipped stone tools recovered came from random surface collections conducted by the crew during water breaks. Although the crew looked for artifacts throughout the week of testing, the tools were found only in the first two days; indicating that recovery of tools during surface collection was fairly complete.

The shallow depth of deposits and the very clear stratigraphy exhibited by the Gradall trenches indicated that the modern surface, or a less deflated surface, was present at the time the site was originally occupied. Because of the lack of depth of deposits and lack of features, the site is not recommended for further investigation. 


\section{This Page Redacted Per THC Policy}


Site 41FB191 is within the Texas Biotic Province (Blair 1950) near its eastern boundary with the Austroriparian Biotic Province. While the western boundary of the Texan Biotic Province is very-defined geologically, the eastern boundary consists of areas of Austroriparian vegetation interfingered with Texan/Prairie vegetation. The area is at the boundary between moisture surplus and moisture deficiency. While sandier soils support oak-hickory forests, tall grasses are found on clayey soils. Blair points out that most of the areas where tall grass was dominant have now been converted to agriculture. Hardwood and pine forests occur along major streams like the Brazos River and portions of Oyster Creek.

Gould (1969) has classified the region as part of the Gulf Prairies and Marshes vegetational area. This zone extends across the entire coast of Texas and includes all of Fort Bend and Most of Harris County. He divides this area into the Coastal Prairie in the interior of the area, and the Gulf Coast Marshlands immediately along the coastline. The climax vegetation (also described by Blair) includes post-oak savannah and tall grass prairies.

The site locale has an average annual rainfall of 45 inches (Carr 1977:4). The area receives its maximum rainfall in the summer in the form of convective thunderstorm activity (Carr: 14-16). This rainfall pattern is mainly due to the proximity of the region to the waters of the Gulf of Mexico. 
CULTURAL SETTING

Previous Archaeological Research

In the vicinity of site 41FB191, most archaeological research has occurred at Addicks Reservoir and Barker Reservoir to the northeast. In 1947, Wheat (Wheat 1953) conducted a survey of Addicks Reservoir and surrounding vicinity. He examined 9 sites and tested or excavated 6 of them. At 2 of the sites (41HR5 and 41HR7) there were a total of seven burials (Newman 1953). All were flexed or semiflexed, and one had a turtle shell offering which may have been a rattle. Addicks Lake was re-examined in the 1980s (Fields, Freeman and Kotter 1983, Kotter and Fields 1983, and Howard and Freeman 1983).

At Barker Reservoir, Good (1983) conducted a survey along Mason Creek for the Army Corps of Engineers. Archaeologists from Texas A \& M University also conducted a systematic survey of the reservoir (Ensor, Carlson, and Carlson 1983) and later examined sites on the Cinco Ranch, in the western part of the reservoir area (Ensor 1987). One of the most concise discussions of previous archaeological research in the area is given by Fields et al. (1986) who also report 23 new prehistoric sites and another 8 which were previously known in Barker Reservoir.

Walley (1955) reports on investigations at the Albert George Site on Big Creek in southern Fort Bend County. The site contained a substantial cemetery area. Walley visited the site in 1951 and found 3 skeletons, including one of a young female associated with 2 columnella pendants. He revisited the site in 1954, when part of the site was bull-dozed. At that time a number of additional skeletons were found. Also found was a cache of bone tools, decorated bone, a boatstone, Goose Creek Incised pottery, and a collection of dart point (mainly Gary points). Other sites are also known along Big Creek, and a recent survey reports on 4 of these sites (Aronow, Drollinger and Korgel 1988)

In addition to the research described above, Thoms and Montgomery (1977) discuss the region within the context of a statewide description of archaeological sites along the Brazos River. However, their paper gives only cursory treatment of Fort Bend County. Labadie (1987) describes sites to be affected by the All American Pipeline. Once again, the portion of the discussion regarding Fort Bend County is brief and only mentions a site on the San Bernard River (41FB28).

Lisk et al. (1985) examined development tracts just east of Richmond, Texas and reported on 11 archaeological sites. All were historic sites dating from the late 19th or early 20th century, although one had a prehistoric lithic scatter. Duke (1985) briefly describes two prehistoric sites in nothern Fort Bend County from which he made surface collections. Ensor (1984) describes six sites on Buffalo Bayou in northern Fort Bend County.

\section{Chronological Sequence}

Early work by Wheat (1953) suggested a three-part chronology based on mainly on excavations at three sites in the Addicks Reservoir area in western Harris 
County. Wheat's time periods roughly correspond to Paleo-Indian, Archaic, and the Neo-American Stages. Since 1953, Wheat's chronology has been expanded, but not significantly altered. For purposed of this discussion, the following time periods will be used:

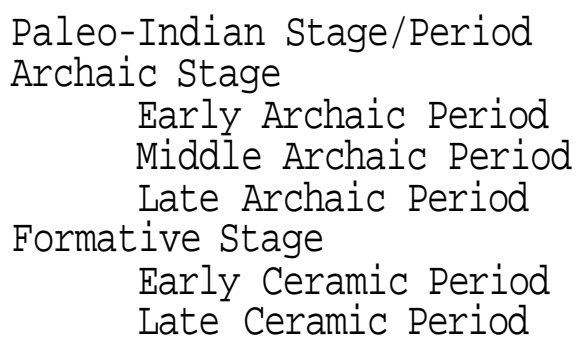

\author{
Before 8000 B.P. \\ 8000-6000 B.P. \\ $6000-4000$ B.P. \\ 4000-1900 B.P. \\ 1900-1200 B.P. \\ 1200-300 B.P.
}

The Paleo-Indian Stage is typified by small groups of nomadic gatherer-hunters who hunted megafauna which are now extinct. Diagnostic artifacts include Plainview, Angostura, San Patrice and Scottsbluff point types. Most of the Paleo-Indian material from the region has been found in isolated finds or secondary deposits (Wheat 1953, Thoms and Montgomery 1977).

During the Archaic Stage, social organization is thought to have been oriented around small gatherer-hunter groups, as in the Paleo-Indian Stage. However, there appears to have been more diversity in food resources and in tool types. Game consisted of extant species of fauna and marine and riverine resources were utilized more. Grinding tools become more common during the Archaic Stage; indicating increasing emphasis on the preparation of seeds and nuts. Temporal divisions within the Archaic are associated with different dart point styles. Early Archaic sites frequently have such dart point types as Bell, Andice, and Wells. Middle Archaic sites have Bulverde, Pedernales, and Travis points. Late Archaic point types include Gary, Kent, Darl, and Ellis points.

During the Formative Stage (also called the Late Prehistoric Period or NeoAmerican Stage), groups of gatherer-hunters still predominated along the Texas Gulf Coast, but there is also evidence of more sedentism. For example, sites with cemetery areas (Walley 1957) are known in southern Fort Bend County. Also grinding tools, pottery and occasional agricultural implements are found.

The Early Ceramic Period (also called the "Woodland" Period) has been defined as the period after the introduction of pottery, but before the appearance of the bow and arrow (Fields et al. 1986:14-18). Pottery from this time period almost invariably has a sandy paste, and Goose Creek Plain, Goose Creek Stamped, and Goose Creek Incised are the dominant wares. Point types overlap with those found in the Late Archaic. Gary points are the most common, along with Kent and Elam.

During the Late Ceramic Period, the pottery becomes more diverse. In addition to the sandy pottery types, grog tempered pottery also occurs, with occasional bone or shell temper. Pottery types of the Late Ceramic Period include Goose Creek Plain, Goose Creek Red Filmed, Baytown, and San Jacinto. A number of arrow points are also found at sites of this time period. These include mainly Scallorn and Perdiz. Alba, Catahoula and Edwards are found. 


\section{SITE DESCRIPTION}

The site is in an agricultural field bounded on the west by a marshy area. The marsh extends northward beyond 41FB191, and then curves to the east. It appears to be spring-fed. The site extends along two terraces which are separated by a gentle slope and are parallel to the east side of the marsh. The field containing the site has been used by the Jester Prison Farm for about 100 years for cotton, corn, hay and other crops, and for grazing cattle. Before the land was cleared, it probably contained a mix of hardwood-pine forest and tall grass prairie vegetation, as is typical of the eastern boundary of the Texas Biotic Province.

Oyster Creek is about 1 kilometer away, but the marsh on the west side of the site is spring fed and could have been used as a source of water at the site throughout the year. Fish and fresh water mussels are found in Oyster Creek, but the general lack of mussel shell at 41FB191 may indicate that Oyster Creek was not used as intensely as at other sites in the area. This also may indicate that Oyster Creek did not flow adjacent to the site at the time that it as occupied. 


\section{TEST EXCAVATIONS}

\section{Field Methods}

During the initial survey of the site in November 1989, an uncontrolled random surface collection was made. Material was scattered across both the upper and lower terrace. Before testing began, a fence was constructed along the proposed west right-of-way and another was built about 50 meters north of the edge of the site. Fences already existed to the south and west. The four fences contained about 4 acres and 41FB191 covers about 1 acre of this area.

Three 1x1 meter test units (Figure 2) were excavated by hand using pickmaddocks, shovels and trowels. The units were dug in $10 \mathrm{~cm}$ levels and all of the soil was screened through 114-inch mesh hardware cloth. In addition to the test units, six shovel tests were excavated. Each of these was about 30 to $50 \mathrm{~cm}$ in diameter and extended to a depth of about 30 to $40 \mathrm{~cm}$. A Gradall was used to excavate three trenches. Trench 1 was on the upper terrace and ran parallel to the terrace edge. Trenches 2 and 3 were longer and extended east-west perpendicular to the two terraces and the terrace edge.

\section{Stratigraphy}

Stratigraphy is shown in Figure 3. While Trenches 2 and 3 areillustrated, Trench 1 had a similar profile. Since Trenches 2 and 3 cut across the terraces, their profiles are more characteristic of the site as a whole. The lower terrace has a plow zone of 20 to $30 \mathrm{~cm}$ consisting of a hard, dry, brown clay (dark brown when moist) with occasional caliche threads. Below this is a moist, reddish brown clay extending to at least 1.5 meters. The upper terrace consists of a similar brown clay plow zone with an underlying moist, reddish brown fine sand or sandy clay.

At the edges between the terraces, there are soil zones which underly the reddish clay of the lower terrace, but cut and/or overlie the reddish fine sand of the upper terrace. From upper to lower, or west to east, these zones can be described as black gleyed clay which breaks into slick, shiny clods, and a reddish brown silty clay. The slope of the deposits at the terrace edge are consistent with the assertion that the deposits represent fill from an ancient stream; possibly Oyster Creek. The deposits are cut by the thin plow zone, which extends across both terraces and the terrace edge more-or-less horizontally. 


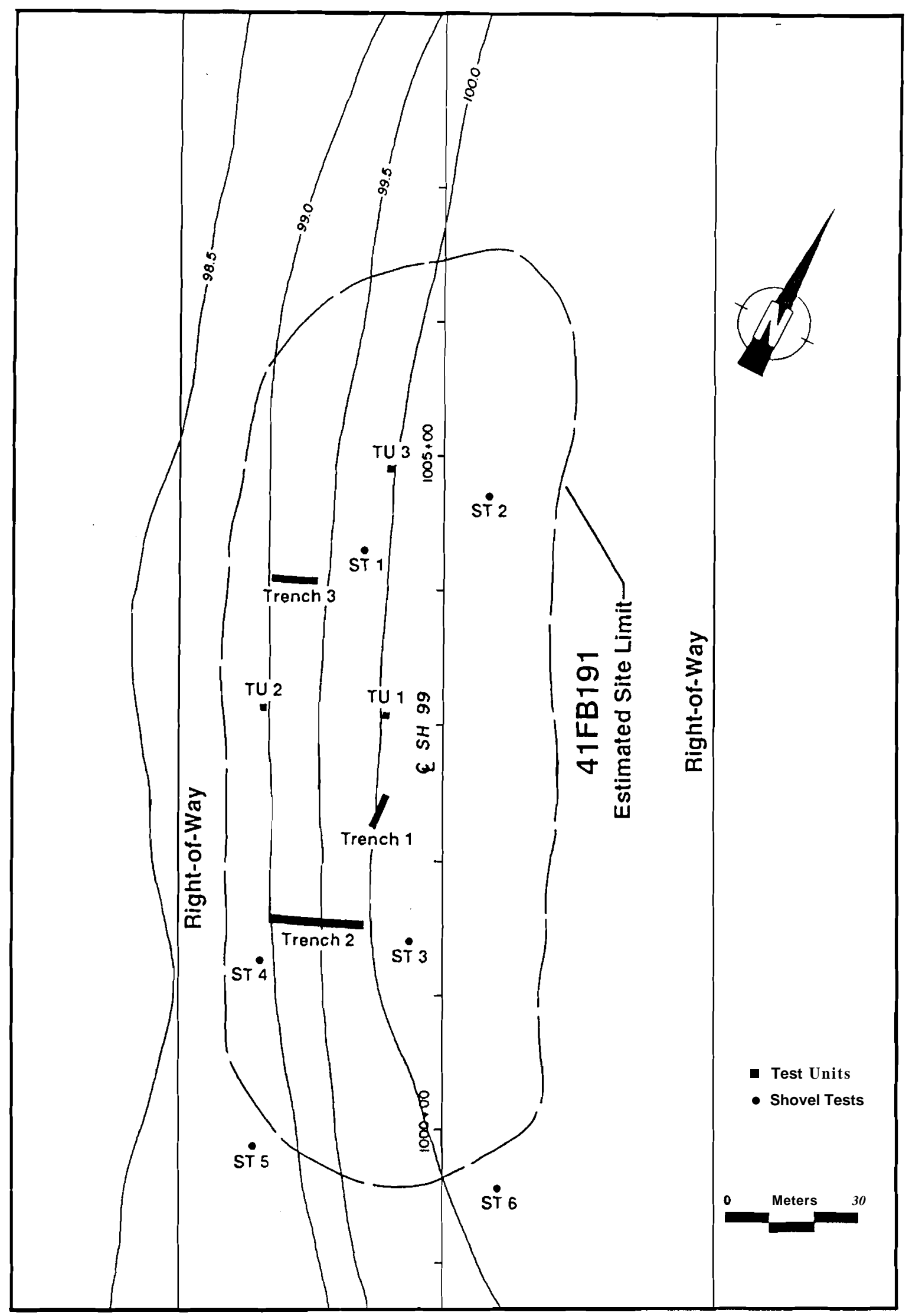

FIGURE 2. Test units, trenches, and shovel test at 41F B 191. 


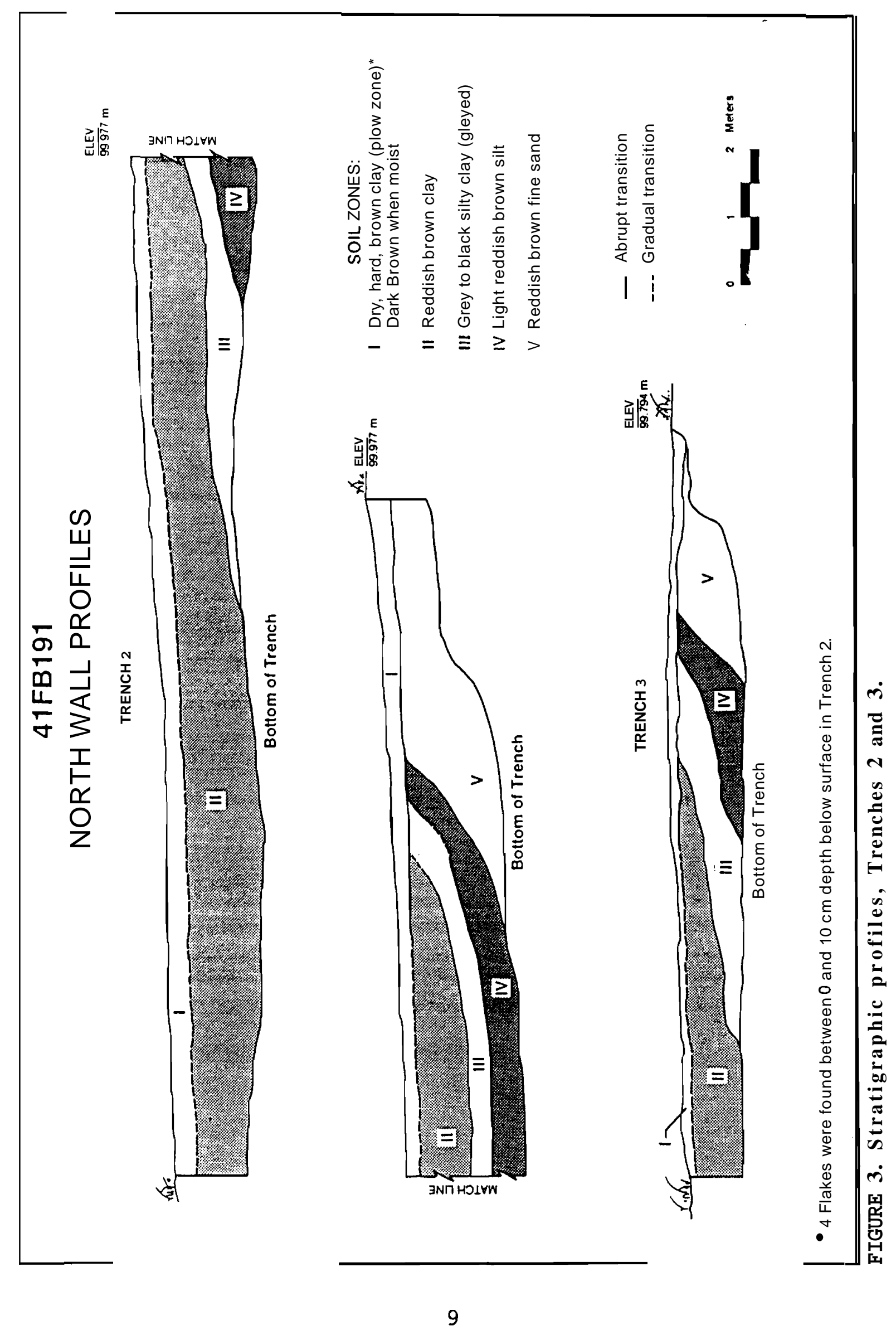


Test Units

\section{TEST UNIT 1}

This test unit was on the west edge of the upper terrace. Very little material was found and most of it came from the upper $10 \mathrm{~cm}$ of the unit. The soil was a hard dry clay in the upper $30 \mathrm{~cm}$, corresponding to Soil Zone 1 i $n$ the trench profiles. The fourth level of the unit was a reddish clay and was sterile in terms of culturla material. This soil corresponds to Soil Zonel in the trench profiles.

\section{TEST UNIT 2}

This test unit was on the lower terrace. Although much of the collected surface material came from near this unit, almost nothing was found subsurface. The soil was a hard, dry clay throughout all three levels, and corresponds to soil Zonel seen in the trench profiles.

\section{TEST UNIT 3}

Test Unit 3 is the only one which showed extensive disturbance below the plow zone. This unit is on the upper terrace and, unlike the other two test units, most of the flakes were found in Level 3 and 4 . However, all of the flakes from these levels came from the northernmost portion of the unit, where there was obvious ant and rodent disturbance (Figure 4). The disturbance began in Level 2 and got progressively larger through Levels 3 and 4 . The disturbance continued in Level 5. The area outside of the disturbed area was devoid of artifacts below Level 2. Therefore, it appears that the material seen in Test Unit 3 below the plow zone was transported downward through more recent rodent and ant activity. Level 5 was sterile with regard to artifacts.

The soil of the upper 38 to $40 \mathrm{~cm}$ of the test unit is a dry, hard clay and corresponds with Soil Zonel from the trench profiles. The soil in Level 5 is a reddish brown sandy clay, and corresponds with Soil Zone V from the trench profiles, the soil in the trenches seemed more sandy in Zone V. 


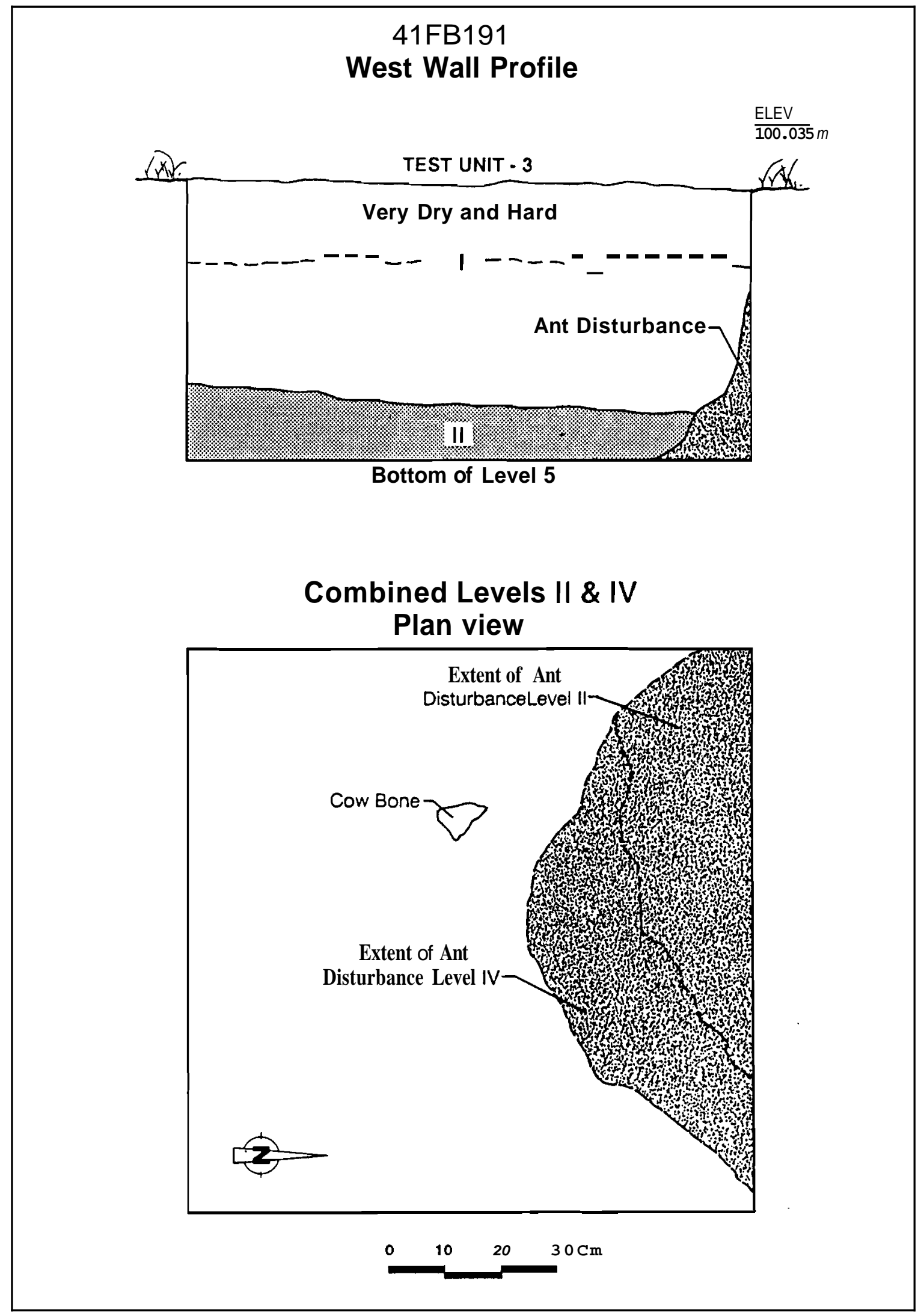

FIGURE 4. Test Unit 3. North wall profile and composite plan view. 


\section{Artifact Descriptions}

Most of the cultural material found at 41FB191 was found on the surface. Artifacts were scarce in all of the test units, except Test Unit 3, Levels 3 and 4. However, Test Unit 3 suffered from animal disturbance in the northern portion of the unit. Flakes were found exclusively within the disturbed portion of the test unit in Levels 3 and 4.

The only artifacts found in the Gradall trenches were 4 flakes which came from the upper $10 \mathrm{~cm}$ of Trench 2. No artifacts were found in the shovel tests, even though the shovel tests were thoroughly searched for artifacts and the fill from two of the shovel tests (ST-1 and ST-2) was screened through 1/4inch hardware cloth.

\section{UNMODIFIED FLAKES}

The cultural material is summarized in Table 1. The sample of flakes from the Test Units is small, but almost all of the flakes were made using soft hammer or pressure flaking techniques. The distribution of flakes by decortication type suggest that the predominate site activity consisted of tool resharpening and/or the final stages of tool-making. One outre-passe flake was found on the surface and is further evidence of such activities.

\section{MODIFIED FLAKE}

One modified flake was found in Test Unit 3, Level 1. It is an interior flake which was probably produced by means of soft hammer percussion. Use-wear is on the dorsal face of the proximal half of the right lateral edge. This edge is slightly concave in outl ine and has a steep (40-60 degrees) edge angle in cross section. The flake exhibits crushing and step fractures along the modified edge. It was probably used for scraping material such as wood or bone, but was abandoned after a brief period of use.

\section{OUTRE-PASSE FLAKE (BIFACIAL)}

An outre-passe flake (Figure 5, a) was found on the surface. Its distal end is the edge of a biface, which was being thinned and shaped. A small amount of cortex can be found on the distal portion of the dorsal face, along the bifacial edge.

\section{BIFACE TIP}

One biface tip was found on the surface (Figure 5, b). It has been broken transversely with a snap fracture, but it is not clear whether the implement was broken prehistorically, or by modern agricultural activity. The biface tip is well-made and is from a finished tool, but exhibits no definite usewear. However, the tips of stone knives typically have use-wear concentrated 


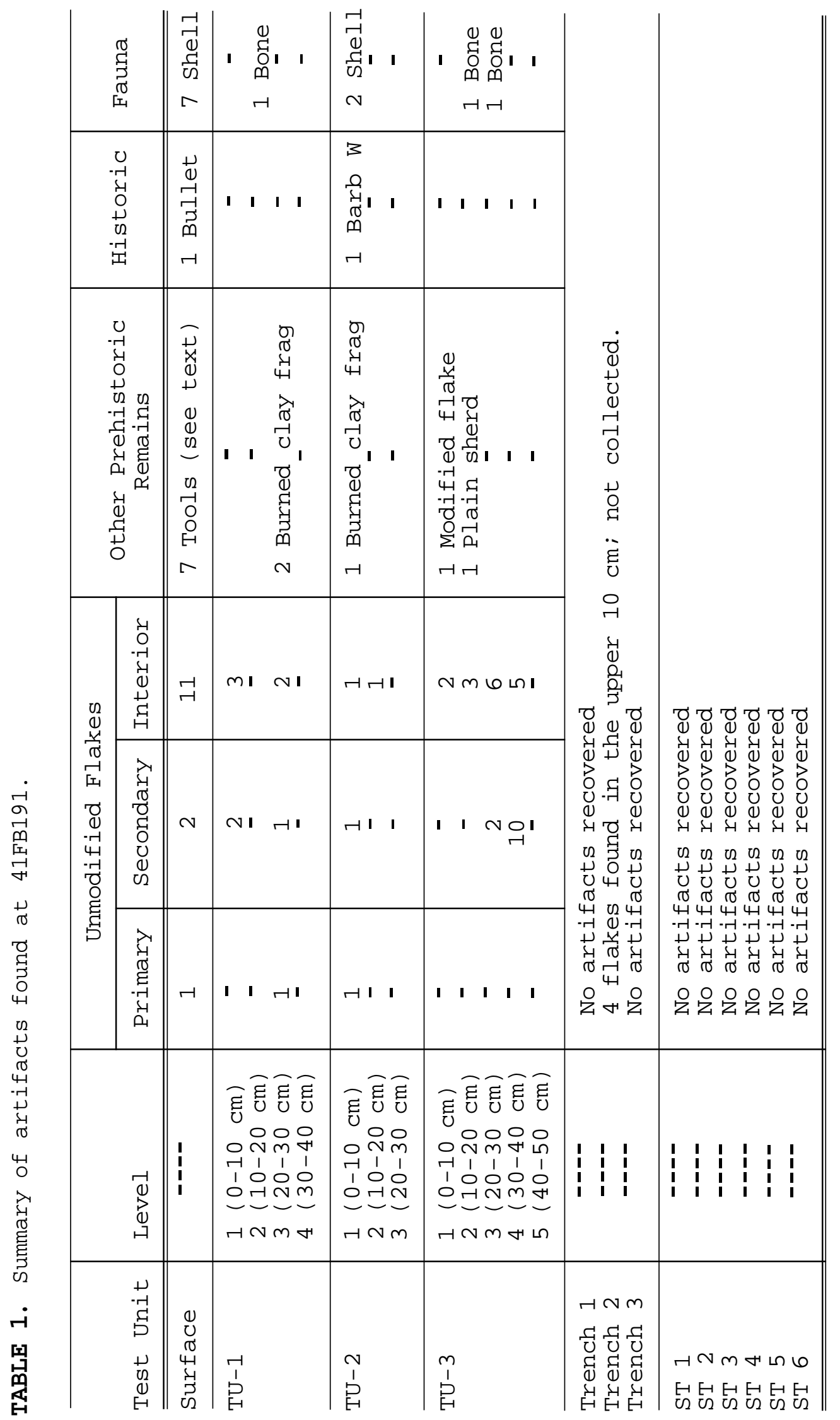




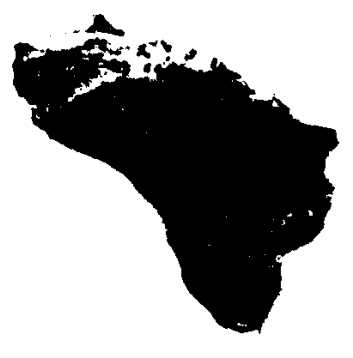

a
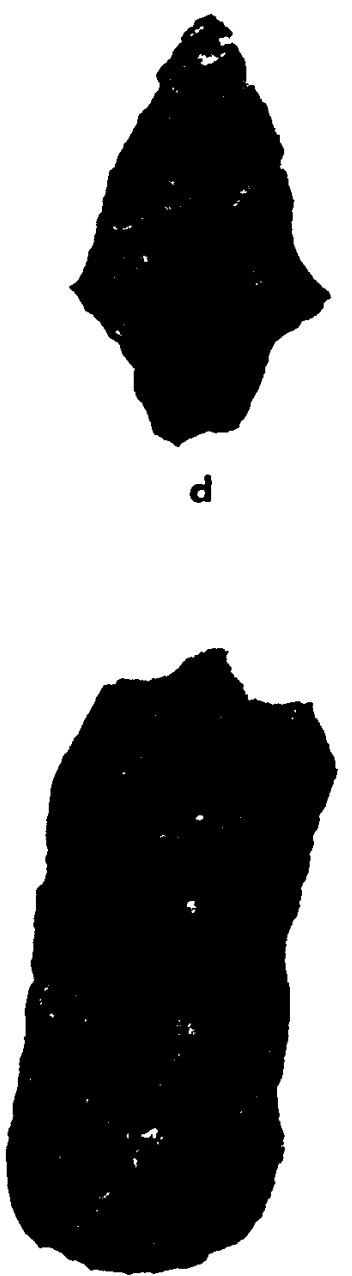

Q

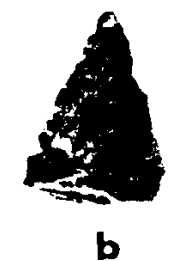

b
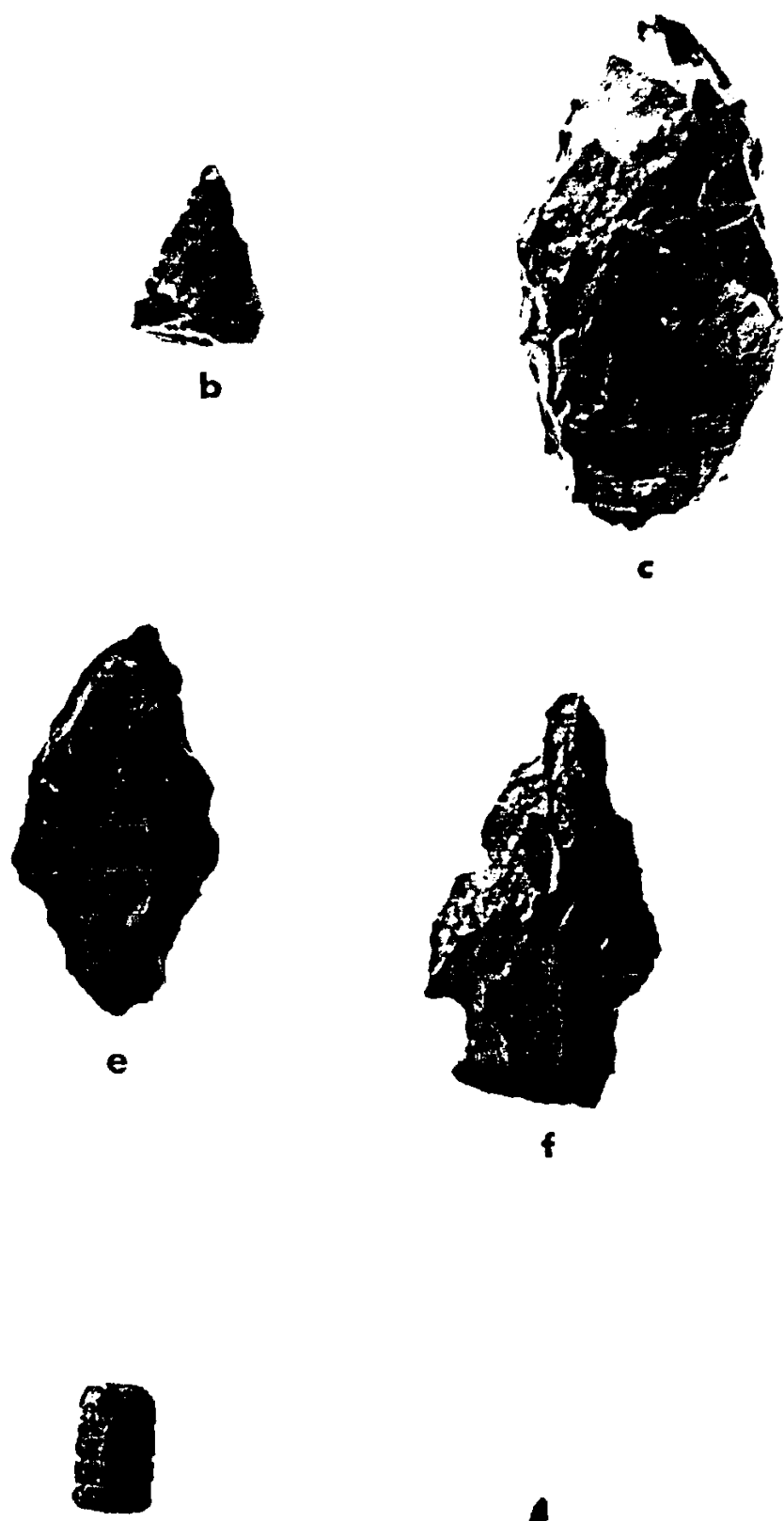

h

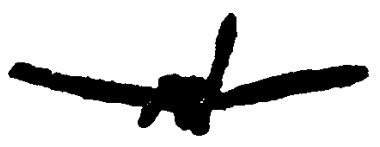
1 in.

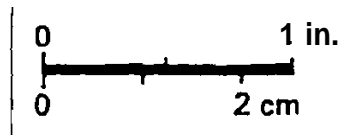

$\mathbf{J}$

FIGURE 5. Artifacts from 41FB191. a, bifacial outre-passe flakes; b, biface tip; c, bifacial keeled scraper; d-f, dart points; g, tested cobble with possible graver spur; h, lead bullet; j, barbed wire fragment. 
in the middle of each edge rather than at the tip and the edges of projectile points frequently exhibit little or no use-wear along the blade.

\section{KEELED SCRAPER (BIFACIAL)}

The keeled scraper (Figure 5, c) was also found on the surface. It has been bifacially worked, with several flakes removed from the ventral (planar) face in order to remove cortex and prepare platforms along the edge. The dorsal (keeled) face was then chipped from these platforms. Small areas of cortex remain on both the vental and dorsal faces. The scraper's outline is that of an elongated ovoid. One end is somewhat pointed while the other end is more rounded in shape. Both edges appear to be unused, although the rounded end may have been re-sharpened just before the scraper was discarded.

The middle portions of each lateral edge have been crushed, ground and smoothed. This may be from rocking in a haft. It is also possible that the tool was used as a side scraper, but it is more likely that the specimen represents an end scraper based on its overall shape and the nature of the use-wear visible on its lateral edges. Similar keeled scrapers are common to East Texas, where they occur frequently in phases contemporaneous with the Early Ceramic period of the upper Texas coast.

\section{DART POINTS}

Three dart points were recovered from the surface. All three are made of chert. Two of these are Gary points and one (Figure 5, d) is well-formed with distinct shoulders, while the other (Figure 5, e) is more crudely shaped. The ubiquitous Gary point style is common in the Early Ceramic period.

The third point (Figure 5, f) has shallow corner notches and a convex base. Although not assigned to a specific point type, the dart is similar to those from the Late Archaic or Early Ceramic period.

\section{TESTED COBBLE (POSSIBLE GRAVER)}

A tested chert cobble was also found on the surface (Figure 5, g). The cobble is rectangular in outline with a planoconvex or triangular lateral crosssection (i.e., short axis perpendicular to the long edges). It has been chipped mainly one one face, while the opposite face is unmodified except at one end. On this end there is a possible graver spur. The tip of the spur appears smoothed and the notches on either side of the spur have been caused by crushing in a direction away from the chipped face.

\section{POTTERY SHERD AND BURNED CLAY FRAGMENTS}

A pottery sherd was found in Test Unit 3, Level 2 . The sherd is plain with a black core and very sandy paste. There is no apparent temper, other than the sandiness of the paste. The sherd may be Goose Creek Plain, which dates to 
the Early Ceramic period. Sandy pottery is typicalof that time period in any case.

Small clay fragments were found in Test Unit 1, Level 3, and Test Unit 2, Level 1. These probably represent eroded sherds, but are less sandy than the pottery sherd from Test Unit 3.

\section{HISTORIC REMAINS}

A lead bullet was found on the surface and a fragment of barbed wire was found in the Test Unit 2, Level 1. The bullet (Figure 5, h) is .41 caliber and may be from a Colt revolver or similar pistol. The barbed wire (Figure 5, j) is single strand of what is probably two-strand Glidden barbed wire; a common barbed wire type.

\section{FAUNAL REMAINS}

Three fragments of mussel shell were found on the surface. Another two very small flakes of mussel shell were found in Test Unit 2, Level 1. Four fragments of Oyster Shell were also found on the surface. One small terrestrial snail shell was collected in Test Unit 2, Level 1, and is of the genus Practicollela.

Three pieces of bone were found. One small fragment occured in Test Unit 1, Level 2, and another in Test Unit 3, Level 3. Both were too fragmentary to be associated with any particular species. The third bone was found in Test Unit 3, Level 2 and represents the distal potion of a cow tibia. 


\section{CONCLUSIONS}

In general there are no indications of cultural deposits below the plow zone at 41FB191. Most of the cultural material found came from the surface. The only test unit which exhibited deeper deposits of cultural material contained this material in the portion of the unit where obvious animal disturbance had occurred. The site appears to be eroded and deflated from many decades of agricultural activity within the last hundred years. The dart points indicate an Early Ceramic time period, but the point types are not particularly timesensitive styles and overlap with the Late Archaic. The sandy pottery present at the site may also indicate an Early Ceramic component.

Since the artifacts are mainly distributed on the surface and in the plow zone, and no features were found in the test units or trenches, construction of SH 99 (Grand Parkway) will not disturb significant archaeological remains at this location. This site does not meet the criteria for inclusion in the National Register of Historical Places and no further investigation is. recommended at 41FB191. 


\section{REFERENCES CITED}

Aronow, Saul, Harold Drollinger and Randy Korgel

1988 Archeological and Geomorphological Investigations of the Big Creek Rechannelization and Canal Construction Project. Archeological Surveys No. 5. Archeological Research Laboratory, Texas A \& M University. College Station.

Blair, W Frank

1950 The Biotic Provinces of Texas. Texas Journal of Science 1(2):93116.

Carr, John T.

1977 The Climate and Physiography of Texas. Report No. 53. Texas Water Development Board. Austin.

Duke, Bruce R.

1985 Surface Surveys at Sites 41FB101 and 41FB102, Fort Bend County, Texas. Houston Archeological Society Journal No. 81:5-10.

Ensor, H. Blaine, Shawn B. Carlson, and David L. Carlson

1983 Archeological and Historic Investigations of the Harris County Lease, in Barker Reservoir, Harris County, Texas. Archeoloqical Surveys No. 2. Archeological Research Laboratory, Texas A \& M University. College Station.

Ensor, $H$. Blaine

1984 Cultural Resources Survey of the Cinco Ranch Venture Flood Control Project, Fort Bend County, Texas. Report submitted to the Turner, Collie Braden Engineering Consultants. Unpublished manuscript on file at the Texas Archeological Research Laboratory, University of Texas at Austin.

1987 The Cinco Ranch Sites, Barker Reservoir, Fort Bend County, Texas. Reports of Investiqations No. 3. Archeological Research Laboratory, Texas A \& M University. College Station.

Fields, Ross C., Martha Doty Freeman, and Steven M. Cotter

1983 Inventory and Assessment of Cultural Resources at Addicks Reservoir, Harris County, Texas. Report of Investiqations No. 22.

Prewitt and Associates, Inc. Austin.

Fields, Ross C., Molly E. Godwin, Martha Doty Freeman, and Susan V. Lisk. 1986 Inventory and Assessment of Cultural Resources at Barkaer Reservoir, Fort Bend and Harris Counties, Texas. Report of Investiqations No. 40. Prewitt and Associates, Inc. Austin.

Good, Carolyn

1983 Proposed Improvements for Mason Creek, Harris County Flood Control District, Barker Reservoir, Harris County, Texas. Unpublished 
manuscript on file at the U.S. Army Corps of Engineers, Galveston District.

Gould, Frank W.

1969 Texas Plants: A Checklist and Ecological Summary. Texas Agricultural Experiment Station, Texas A \& M University. College Station.

Howard, Margaret A. and Martha Doty Freeman

1983 Inventory and Assessment at Bear Creek Park, Addicks Reservoir, Harris County, Texas. Report of Investiqations No. 24. Prewitt and Associates, Inc. Austin.

Kotter, Steven M. and Ross C. Fields 1983 National Register Testing of Site 41HR436, Addicks Reservoir, Harris County, Texas. Report of Investiqations No. 23. Prewitt and Associates, Inc. Austin.

Labadie, Joseph H. (assembled by)

1987 Cultural and Paleontological Resources of the All American

Pipeline Supplementary Environmental Impact Statement between

McCamey and Webster, Texas. Technical Report. Center for

Archaeological Research, University of Texas at San Antonio.

Lisk, Susan V., Martha Doty Freeman, Gail Bailey, and Ross C. Fields

1985 Inventory and Assessment of Cultural Resources at the Fort Bend Partners Venture Tract and Watson Tract, Fort Bend County, Texas. Report of Investiqations No. 42. Prewitt and Associates, Inc. Austin.

Newman, Marshall T.

1953 Indian Skeletal Remains from the Doering and Kobs Sites, Addicks

Reservoir, Texas. River Basin Survey Papers 4, part 1. Bureau of American Ethnology Bulletin 154:253-266. Washington, D.C.

Thoms, Alston V. and John L. Montgomery

1977 The Archeological Resources of the Brazos River Basin: A Summary Statement. Department of Anthropology, Texas Tech University, Lubbock Texas. Unpublished manuscript prepared for the U.S. Army Corps of Engineers, Fort Worth District. O $n$ file at the Texas Archeological Research Laboratory, University of Texas at Austin.

Walley, Raymond

1955 A Preliminary Report on the Albert George Site in Fort Bend County. Texas Archeological Society Bulletin 26:218-234.

Wheat, Joe Ben

1953 The Addicks Dam Site: An Archeological Survey of the Addicks Dam Basin, Southeast Texas. River Basin Survey Papers no. 4, part 1. Bureau of American Ethnology Bulletin 154:143-252. Washington, D. C. 